\title{
IDENTIFICATION AND CHARACTERIZATION OF YEAST ISOLATES FROM MAPRANG (Bouea macrophylla Griffith) GROWING IN VIETNAM
}

\author{
NGO VAN TAI ${ }^{1 *}$ and NGUYEN VAN THANH ${ }^{2}$ \\ ${ }^{I}$ Department of Food Technology, College of Agriculture, Can Tho University, \\ 900000, Can Tho, Vietnam \\ ${ }^{2}$ Biotechnology Research and Development Institute, Can Tho University, \\ 900000, Can Tho, Vietnam \\ *E-mail: vantai@ctu.edu.vn
}

Accepted 17 September 2020, Published online 25 October 2020

\begin{abstract}
Fifteen yeast strains isolated from maprang (Bouea macrophylla Griffith) were characterised using standard microbiological procedures. The species were identified belonging to three genera Saccharomyces, Hanseniaspora and Pichia and their abilities for wine production were tested by analysing the alcohol produced and remaining sugar. The best biochemically active strain was used along with commercial yeast ( $S$. cerevisiae) to produce wine from maprang juice. Fermenting activity of isolated yeasts was higher than commercial yeast. The isolated yeast strain namely $3.5 \mathrm{~B}$ and $5.5 \mathrm{~A}$ showed the best fermenting activity such as fast fermentation by Durham test and highest alcohol percentage $(11.5$ and $11.83 \% \mathrm{v} / \mathrm{v})$. Based on the $28 \mathrm{~S}$ rRNA sequences, yeast strain 5.5A and 3.5B showed 99\% similarity to S. cerevisiae (KP723678.1 and KF728774.1, respectively). Using isolated yeast strain 5.5A for wine fermentation at $\mathrm{pH} 4.0$, total soluble solid content $24 \%$ and inoculated with yeast density of $10^{7}$ cells $/ \mathrm{mL}$, the alcohol content produced was $14.5 \% \mathrm{v} / \mathrm{v}$ and the wine had favorable color and flavor. Our work constitutes a foundation for strain selection for future applications as starter cultures in fruit wine fermentations. This work is the first ever on yeast diversity from maprang which is the special fruit of Vinh Long province, Vietnam.
\end{abstract}

Key words: Characterisation, yeast identification, maprang, yeast strain, wine production, 28S rRNA analysis

\section{INTRODUCTION}

Bouea macrophylla, commonly known as maprang and gandaria in English, is a species of flowering plant native to Southeast Asia, and in Vietnamese called as thanh trà. In Vietnam, there is a special area of maprang tree growing. Due to the high farming technique, the fruit showed promise for greater commercial production in Vietnam. Maprang grown in Vietnam contains high amount of water $(86.6 \%)$, protein $(40 \%)$, carbohydrate $(13 \%), \beta$ carotene (25\%) and vitamin C (38\%) (Thuy et al., 2018). Maprang is a soft fibrous fruit that yields a highly nutritious juice, which is good for digestion and also can be utilised for the preparation of other value-added products. Among the fruits that have the potential for the production of wine, maprang presents appropriate characteristics such as sugar content, $\mathrm{pH}$, strong flavor and best color (Thuy et

\footnotetext{
* To whom correspondence should be addressed.
}

al., 2018). However, these fruits are highly perishable, and susceptible to bacterial and fungal contamination as a result they fail to reach the market due to spoilage.

Wine-making is a process of fermentation that involves production of ethanol. Yeasts play a key role in the fermentation process. The term wine is only used for the fermentation of grapes, however, many other fruits can be used in the same process (Dorneles et al., 2005), as well as other species of yeasts associated to these fruits (Vadkertiová et al., 2012). The most commonly used strain for ethanol production is Saccharomyces cerevisiae. However, there is limited information available about the effect of various factors on the fermentation profile of maprang wine even by using commercial yeast or isolated yeast strains from these fruits. Fermentation by isolated yeasts has many advantages such as good flavor, high alcohol concentration and low sugar content. This work focused on the characterisation and identification 
of local yeast strains from the fresh pulps of maprang collected in Vinh Long, Vietnam. Screening and selection of pure yeast are important to select the high biological activity of yeast with the best fermentation ability. This study revealed the possibility of producing wine from locally available fruits using simple and adaptable technology with biochemically characterised yeast strains.

\section{MATERIALS AND METHODS}

All the research work was carried out in the Laboratory of Food Technology, College of Agriculture and Laboratory of Food Biotechnology, Biotechnology Research and Development Institute, Can Tho University, Vietnam.

\section{Isolation of yeasts}

Maprang were collected from Dong Thanh and Dong Binh commune, Binh Minh district, Vinh Long province.

Yeast Extract-Peptone-Dextrose (YPD) medium was prepared. Reagents were dissolved in $1 \mathrm{~L}$ of distilled water and autoclaved for $20 \mathrm{~min}$ at $121^{\circ} \mathrm{C}$ then stored at room temperature. Maprang fruit (without peeling) of $50 \mathrm{~g}$ were sliced and placed in prepared YPD medium (in erlenmeyer flask $100 \mathrm{~mL}$ ) and shaked at $28 \pm 2{ }^{\circ} \mathrm{C}$ for about 2 days. Series of dilution was done $\left(10^{-1}, 10^{-2}, 10^{-3}, 10^{-4}, 10^{-5}\right)$ and $1 \mathrm{~mL}$ of appropriate dilution was plated (using the standard pour plating technique) onto YDPA medium, the petri dishes were incubated upside down at $30^{\circ} \mathrm{C}$ for $48 \mathrm{hr}$.

\section{Purification of yeasts}

Single colonies of representative isolates were purified following the dilution plating technique in the agar medium. Separated colonies were transferred again to the agar slants. Purification was done by streaking on plated agar and repeated two or three times or until pure cultures were obtained, as confirmed by microscopic examination. Purified yeast cultures were identified through morphological, biochemical tests and DNA sequencing.

\section{Morphological characteristics}

Morphological distinguished colonies were then selected under a dissection microscope. The isolates were grouped according to their colonial morphology and cell characteristics. The colonies were counted and re-isolated in pure culture using the medium on which they had grown. The shape, color, size of colonies and yeast cells, which were present on the nutrient medium were examined by naked eyes and under the microscope, respectively. Fifteen yeast strains were isolated and coded as
2.5A, 3.4A, 3.5A, 4.5A, 5.5A, 6.5A, 2.5B, 3.5B, $4.5 \mathrm{~B}, 5.5 \mathrm{~B}, 6.4 \mathrm{~B}, 6.5 \mathrm{~B}, 4.5 \mathrm{C}, 6.5 \mathrm{C}, 1.5$. All these strains were store in YPD medium (in $5 \mathrm{~mL}$ agar slant tube/eppendorf tube $200 \mu \mathrm{L}$ YPD medium and $200 \mu \mathrm{L}$ glycerol) at $4{ }^{\circ} \mathrm{C}$ to maintain the original characteristics of yeast strains, recorded and labeled carefully.

\section{Biochemical characteristics of yeasts}

Biochemical characteristics of fifteen isolated yeast strains were defined through sugar fermentation test (Kurtzman \& Fell, 1998) and urease test (Christensen, 1946).

Identification of yeast isolates by DNA Sequencing

The selected yeast strain was identified by sequencing $28 \mathrm{~S}$ rRNA. The sequenced gene consists of 801-805 nitrogen bases and this gene segment is compared with yeast 28S rRNA genes was deposited in the GenBank database on NCBI with BLASTN software.

\section{Fermentation and yeast activity test}

Maprang juice was adjusted to $\mathrm{pH} 4.5$, total soluble solid content $23 \%$ and sterilized by $\mathrm{NaHSO}_{3}(140 \mathrm{mg} / \mathrm{L})$ for $2 \mathrm{hr}$. The yeast cells were inoculated at density of $10^{6}$ cells $/ \mathrm{mL}$, and left to be fermented at $30^{\circ} \mathrm{C}$. Analysis was made at the end of fermentation (about 10 days). From there, the most biochemically active strain was selected.

\section{Wine fermenting by selected yeast strains}

Maprang juice was prepared at different $\mathrm{pH}$ $(3.5,4,4.5)$, total soluble solid content (TSS) (22, $24,26 \%)$, yeast cell numbers $\left(10^{3}, 10^{5}\right.$ and $10^{7}$ cells/ $\mathrm{mL}$ ) and fermented about 10 days at $30^{\circ} \mathrm{C}$. Samples were analyzed at the end of fermentation (10 to 12 days).

\section{Data collection and analysis}

\section{Observation}

The shape, colony size and yeast cells cultured in the nutrient medium were observed by naked eyes and under microscope. The number of colonies/dish, the yeast cells/mL sample were counted and yeast identification was carried out.

\section{Yeast activity test}

The chemical analysis of maprang juice was carried out, including measuring $\mathrm{pH}$ value, residual sugar content $(\%)$ and alcohol content $(\% \mathrm{v} / \mathrm{v})$ (AOAC, 2005). The total yeast counts were observed according to Ndip et al. (2001).

\section{Sensory evaluation}

Maprang wine (after aging for 1 month) was evaluated by 50 panelists. The observations on 
color, clarity, odor and taste were recorded. The score ranging from 1-5 and the highest score (5) was expressed for excellent maprang wine quality. The typical Spidergram was performed.

\section{Statistical analysis}

Chemical analyses were repeated three times for each sample. The one way analysis of variance (ANOVA), and Duncan multiple comparison test to measure variation between treatments at a probability level of $p<0.05$ was applied.

\section{RESULTS AND DISCUSSION}

\section{Characterisation of yeast strains from maprang fruit}

\section{Urea assimilation test}

Colony morphology varied between isolates. All colonies were off-white to cream, and butyrous, dry or rough in surface appearance. Based on classification keys, morphological, biochemical and budding characteristics and spore formation (Kurtzman \& Fell, 1998) (Table 1), the fifteen yeast strains isolated from maprang belonged to the genera Saccharomyces, Hanseniaspora and Pichia.

The yeast strains of group 1 (3.5B, 4.5C, 5.5A - spherical shape), group 2 (3.5A, 5.5B - small oval shape), group $3(6.4 \mathrm{~B}, 6.5 \mathrm{~B}, 6.5 \mathrm{C}$ - large oval) and group 4 (3.4A, 4.5A, 6.5 A - long ellipsoidal) showed the same characteristics as the yeast shape are round, oval, ellipsoidal, haploid cells axial budding reproduced sexually by forming spores, each spore containing 1-2, 1-3 and 1-4 round spore, sugar fermentation, no urea assimilation. These characteristics are similar to the description of morphological characteristics, a preliminary classification of the genus Saccharomyces by Luong et al. (2003), Kurtzman and Fell (1998) described similar Saccharomyces vegetative cells budded in various directions, round, ovate, oval or ellipsoidal shape extended, forming 1-4 round spores, ovoid, smooth surface, sugar fermentation and no urea assimilation. Thus it can be concluded 11 yeast strains 3.5B, 4.5C, 5.5A, 3.5A, 5.5B, 6.4B, 6.5B, $6.5 \mathrm{C}, 3.4 \mathrm{~A}, 4.5 \mathrm{~A}, 6.5 \mathrm{~A}$ belong to Saccharomyces genus.

Furthermore, two yeast strains of group 5 (2.5A, 4.5B - pointed ellipsoidal) shown similar characteristic shape (ellipsoidal yeast cells and pointed at both ends) vegetative cells of bipolar budding, formation of 1-4 spheres spore, hemispheres, sugar fermentation and no ability to produce urease. These characteristics are consistent with descriptions of Kurtzman and Fell (1998) and Ebabhi et al. (2013) for morphological characteristics of Hanseniaspora genus, such as bipolar budding, sexual reproduction by forming 1-4 spheres spores, hemispheres, sugar fermentation and no ability to activate urease. On that basis, it can be concluded that the two isolated yeast strains 2.5A, 4.5B belong to Hanseniaspora genus.

In 15 yeast strain isolates cultured in Christensen medium, two yeast strains $(1.5,2.5 \mathrm{~B})$ belonged to the long ellipsoidal yeast cell group

Table 1. Summary of morphological, biochemical characteristics, and preliminary classification of isolated yeast strains

\begin{tabular}{|c|c|c|c|c|c|c|c|}
\hline \multirow{3}{*}{$\begin{array}{l}\text { Yeast } \\
\text { strains }\end{array}$} & \multicolumn{3}{|c|}{ Morphological characteristics } & \multicolumn{3}{|c|}{ Physiological and biochemical characteristics } & \multirow{3}{*}{$\begin{array}{c}\text { Genera } \\
\text { (Preliminary } \\
\text { classification) }\end{array}$} \\
\hline & \multirow{2}{*}{$\begin{array}{l}\text { Yeast } \\
\text { shape }\end{array}$} & \multirow{2}{*}{ Budding } & \multirow{2}{*}{$\begin{array}{l}\text { Spore } \\
\text { forming }\end{array}$} & \multicolumn{2}{|c|}{ Sugar fermentation test } & \multirow{2}{*}{ Urease test } & \\
\hline & & & & Glucose & Saccharose & & \\
\hline $\begin{array}{l}3.5 \mathrm{~B} \\
4.5 \mathrm{C} \\
5.5 \mathrm{~A}\end{array}$ & Spherical & $\begin{array}{l}\text { Axial/ } \\
\text { multilateral }\end{array}$ & $1-2$ & + & + & - & Saccharomyces \\
\hline $\begin{array}{l}3.5 \mathrm{~A} \\
5.5 \mathrm{~B}\end{array}$ & $\begin{array}{l}\text { Small } \\
\text { Oval }\end{array}$ & $\begin{array}{l}\text { Axial/ } \\
\text { multilateral }\end{array}$ & $1-3$ & + & + & - & Saccharomyces \\
\hline $\begin{array}{l}6.4 \mathrm{~B} \\
6.5 \mathrm{~B} \\
6.5 \mathrm{C}\end{array}$ & $\begin{array}{l}\text { Large } \\
\text { Oval }\end{array}$ & $\begin{array}{l}\text { Axial/ } \\
\text { multilateral }\end{array}$ & $1-2$ & + & - & - & Saccharomyces \\
\hline $\begin{array}{l}1.5 \\
2.5 B\end{array}$ & $\begin{array}{l}\text { Long } \\
\text { Ellipsoidal }\end{array}$ & $\begin{array}{l}\text { Axial/ } \\
\text { multilateral }\end{array}$ & $1-4$ & + & - & + & Pichia \\
\hline $\begin{array}{l}3.4 \mathrm{~A} \\
4.5 \mathrm{~A} \\
6.5 \mathrm{~A}\end{array}$ & $\begin{array}{l}\text { Long } \\
\text { Ellipsoidal }\end{array}$ & $\begin{array}{l}\text { Axial/ } \\
\text { multilateral }\end{array}$ & $1-4$ & + & - & - & Saccharomyces \\
\hline $\begin{array}{l}2.5 \mathrm{~A} \\
4.5 \mathrm{~B}\end{array}$ & $\begin{array}{l}\text { Pointed } \\
\text { Ellipsoidal }\end{array}$ & Bipolar & $1-4$ & + & - & - & Hanseniaspora \\
\hline
\end{tabular}

Notes: + : positive; - : negative. 
that made the medium turn pink (Figure 1). These two yeast strains could produce urease to break down urea and also have similar characteristics such as haploid cells axial budding and sugar fermentation. The research of Ebabhi et al. (2013) also reported that urea hydrolysis was very vigorously registered by Pichia genus. These characteristics are similar to the description of morphological varieties of Pichia (Kurtzman \& Fell, 1998). Thus it can be concluded the two yeast strains $(1.5,2.5 \mathrm{~B})$ belong to Pichia genus.

\section{Screening and identification of yeast strains from maprang collected in Vinh Long, Vietnam}

\section{Propagation of isolated yeasts}

The number of yeast cells during propagation in maprang juice was collected, the yeast cell numbers of 11 yeast strains were about $10^{7}$ cells $/ \mathrm{mL}$ maprang juice after one propagative day. After two days of propagation, $10-40 \%$ budding cells could be observed, dead cells did not exceed $4 \%$ and yeast cell number of $10^{7}$ cells $/ \mathrm{mL}$. The obtained results showed that two days of propagation is appropriate for yeast activation (incubation at $30^{\circ} \mathrm{C}$ with shaking at $140 \mathrm{rpm})$. This result is consistent with the previous results (Thuy et al., 2013a; Thuy et al., 2013 b), a good yeast culture for wine making consists of 12-14 million of yeast cells per mL of yeast culture, from 10 to $15 \%$ of budding yeast cells and low number of dead cells (below 4\%).

\section{Selection of the highest fermentation activity yeast strain from the isolated strains}

Eleven yeast strains were selected $(3.4 \mathrm{~A}, 3.5 \mathrm{~A}$, 3.5B, 4.5A, 4.5C, 5.5A, 5.5B, 6.4B, 6.5A, 6.5B, $6.5 \mathrm{C})$ to carry out the fermentation process along with the commercial Saccharomyes cerevisiae (TM) yeast strain to determine the highest fermentation efficiency yeast strain.

\section{The height of $\mathrm{CO}_{2}(\mathrm{~cm})$ produced in Durham test tubes}

By Durham tube testing, the yeast strain 5.5A (Saccharomycessp) isolated from maprang collected at Dong Binh commune, Vinh Long) had the shortest time $(8 \mathrm{hr})$ to push the maximum height $(3.2 \mathrm{~cm})$ of Durham tubes compared to the other yeasts (Table 2). It can be concluded that the yeast strain 5.5A has the highest fermentative activity.

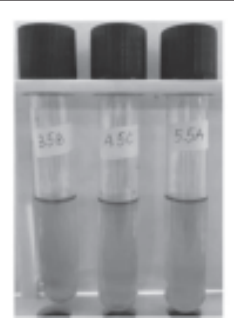

(1) $3.5 \mathrm{~B}, 4.5 \mathrm{C}, 5.5 \mathrm{~A}$

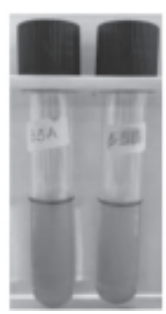

(2) $3.5 \mathrm{~A}, 5.5 \mathrm{~B}$

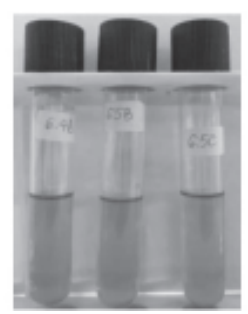

(3) $6.4 \mathrm{~B}, 6.5 \mathrm{~B}, 6.5 \mathrm{C}$

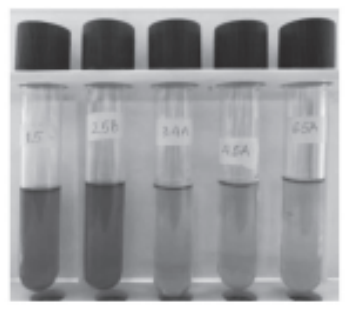

(4) $1.5,2.5 \mathrm{~B}, 3.4 \mathrm{~A}, 4.5 \mathrm{~A}, 6.5 \mathrm{~A}$

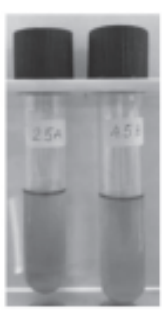

(5) $2.5 \mathrm{~A}, 4.5 \mathrm{~B}$

Fig. 1. Color changes of Christensen medium after inoculation and incubation of 15 yeast strains.

Table 2. The height of $\mathrm{CO}_{2}(\mathrm{~cm})$ produced in Durham test tubes of isolated yeast strains in comparison to commercial yeast strain after 10 days of fermentation

\begin{tabular}{|c|c|c|c|c|c|c|}
\hline \multirow{3}{*}{ Yeast strain } & \multicolumn{6}{|c|}{ The height of $\mathrm{CO}_{2}(\mathrm{~cm})$} \\
\hline & \multicolumn{6}{|c|}{ Fermentation time (hrs) } \\
\hline & 2 & 4 & 6 & 8 & 10 & 12 \\
\hline $3.4 \mathrm{~A}$ & 0.1 & 0.5 & 1.2 & 1.8 & 2.5 & 3.0 \\
\hline $3.5 \mathrm{~A}$ & 0 & 0.3 & 0.7 & 1.7 & 2.2 & 2.8 \\
\hline 3.5B & 0.2 & 1.3 & 2.2 & 2.9 & 3.2 & - \\
\hline $4.5 \mathrm{~A}$ & 0.2 & 0.6 & 1.1 & 1.9 & 2.6 & 3.1 \\
\hline $4.5 \mathrm{C}$ & 0.3 & 1.0 & 1.7 & 2.2 & 2.9 & 3.2 \\
\hline $5.5 \mathrm{~A}$ & 0.1 & 1.4 & 2.6 & 3.2 & - & - \\
\hline $5.5 \mathrm{~B}$ & 0.2 & 0.8 & 1.6 & 2.1 & 2.6 & 3.1 \\
\hline $6.4 \mathrm{~B}$ & 0.3 & 0.5 & 1.3 & 1.9 & 2.5 & 2.8 \\
\hline $6.5 \mathrm{~A}$ & 0.3 & 1.1 & 1.9 & 2.6 & 3.2 & - \\
\hline $6.5 \mathrm{~B}$ & 0.2 & 0.7 & 1.4 & 2.5 & 3.2 & - \\
\hline $6.5 \mathrm{C}$ & 0.1 & 0.5 & 1.2 & 2.0 & 2.7 & 3.2 \\
\hline TM & 0.3 & 1.2 & 1.8 & 2.3 & 3.0 & 3.2 \\
\hline
\end{tabular}

(Note: The height of $\mathrm{CO}_{2}$ column does not change). 
This result is consistent with the previous results (Thuy et al., 2011; Thanh et al., 2013), the fermentation ability of isolated yeasts from palm and pineapple also based on their gas production in Durham test and the selected yeast strain was fast and strong ability of gas production.

\section{The average of alcohol percent and soluble solid content of maprang wine}

After 10 days of fermentation, the alcohol percent of maprang wine are shown in Table 3 . The alcohol content of maprang wine ranged from 5 to $11.83 \%(\mathrm{v} / \mathrm{v})$. However, maprang wine produced by using yeast strains $3.5 \mathrm{~B}, 5.5 \mathrm{~A}$, TM obtained the highest percentage of alcohol $(11.50,11.83$ and $11.33 \%$, respectively), lowest residue sugar $(7.5,7$ and $8.5 \%$, respectively) and showed significant differences when compared with other value obtained from remaining yeast strains.

Thus, combining the results of measuring the height of $\mathrm{CO}_{2}(\mathrm{~cm})$ produced in Durham test tubes, the alcohol percentage, the total soluble solid content after fermentation, it was observed that the isolated yeast strain $5.5 \mathrm{~A}$ had the shortest time to push gas in the Durham tube ( $8 \mathrm{hr})$, high alcohol percent $(11.83 \% \mathrm{v} / \mathrm{v})$ and low TSS $(7 \%)$. Therefore, this isolated yeast strain was considered to exhibit the highest fermentation activity and was selected to carry out the next experiment.

Identification of yeast strains that were selected from isolated yeast strains from maprang

After selecting the highest yeast fermentation activity, two yeast strains $3.5 \mathrm{~B}$ and $5.5 \mathrm{~A}$ were identified using 28S rRNA sequencing (FIRST BASE LABORATORIES, Malaysia).

The sequenced gene consists of 801 nitrogen bases and this gene segment is compared with yeast
28S rRNA genes was deposited in the GenBank database on NCBI with BLASTN software. The results showed that the $28 \mathrm{~S}$ rRNA gene fragment of yeast strain $3.5 \mathrm{~B}$ was $99 \%$ similarity to the $28 \mathrm{~S}$ rRNA sequence of Saccharomyces cerevisiae (KF728774.1).

The 5.5A yeast strain was identified by sequencing $28 \mathrm{~S}$ rRNA. The sequenced gene consists of 805 nitrogen bases and this gene segment is compared with yeast 28S rRNA genes deposited in the GenBank database on NCBI with BLASTN software. The results showed that the 28S rRNA gene segment of yeast strain 5.5A shared 99\% similarity to the 28S rRNA gene sequence of Saccharomyces cerevisiae (KP723678.1).

\section{Effect of total soluble solid content, yeast density} and $\mathrm{pH}$ on maprang wine

The effect of total soluble solid content, $\mathrm{pH}$, the initial inoculated density of yeast cells on Brix, $\mathrm{pH}$ and alcohol content of the maprang wine during fermentation is presented in Table 4. The alcohol content of the wine with initial pH 4.5 (TSS content $24 \%$ and $10^{7} \mathrm{CFU} / \mathrm{mL}$ ) was found to be the highest $(14.5 \% \mathrm{v} / \mathrm{v})$. With an increase in total soluble solid content, alcohol percent does not increase linearly. Similar observations were reported by Satav and Pethe (2016). Low alcohol percentage was found at another $\mathrm{pH}$. This might be due to the inhibition of growth of other microbial flora at lower $\mathrm{pH}(<4.5)$ and more alcohol production by yeast. Various factors such as $\mathrm{pH}$, temperature, concentration of sugars, can affect the physicochemical parameters of wine during its fermentation. $\mathrm{pH}$ is one of the important factors which affects the growth and metabolism of yeast (Satav \& Pethe, 2016). Generally acidic $\mathrm{pH}$ is favourable for wine producing microorganisms and the optimum $\mathrm{pH}$ for

Table 3. Alcohol content ( $\% \mathrm{v} / \mathrm{v})$ and soluble solid content (\%) of maprang wine fermented by using eleven isolated and commercial yeast strains

\begin{tabular}{cccc}
\hline No & Yeast strains & Alcohol content $(\% \mathrm{v} / \mathrm{v})$ & Soluble solid ('Brix) \\
\hline 1 & $3.4 \mathrm{~A}$ & $6.00^{\mathrm{cd}}$ & $13.00^{\mathrm{de}}$ \\
2 & $3.5 \mathrm{~A}$ & $8.50^{\mathrm{bc}}$ & $10.50^{\mathrm{abcd}}$ \\
3 & $3.5 \mathrm{~B}$ & $11.50^{\mathrm{a}}$ & $7.50^{\mathrm{ab}}$ \\
4 & $4.5 \mathrm{~A}$ & $7.33^{\mathrm{bcd}}$ & $11.00^{\mathrm{bcde}}$ \\
5 & $4.5 \mathrm{C}$ & $5.00^{\mathrm{d}}$ & $14.50^{\mathrm{e}}$ \\
6 & $5.5 \mathrm{~A}$ & $11.83^{\mathrm{a}}$ & $7.00^{\mathrm{a}}$ \\
7 & $5.5 \mathrm{~B}$ & $6.83^{\mathrm{bcd}}$ & $12.00^{\mathrm{cde}}$ \\
8 & $6.4 \mathrm{~B}$ & $8.17^{\mathrm{bc}}$ & $11.00^{\mathrm{bcde}}$ \\
9 & $6.5 \mathrm{~A}$ & $7.17^{\mathrm{bcd}}$ & $11.83^{\mathrm{cde}}$ \\
10 & $6.5 \mathrm{~B}$ & $9.33^{\mathrm{ab}}$ & $9.67^{\mathrm{abcd}}$ \\
11 & $6.5 \mathrm{C}$ & $6.33^{\mathrm{cd}}$ & $12.50^{\mathrm{de}}$ \\
12 & TM & $11.33^{\mathrm{a}}$ & $8.50^{\mathrm{abc}}$ \\
\hline
\end{tabular}

*Data are means of triplicates. Means in column with different letters are significantly different according to LSD test ( $p<0.05)$; TM: commercial yeast (Saccharomyces cerevisiae). 
Table 4. Effect of controlled Brix, $\mathrm{pH}$, inoculated density of yeast cells on Brix level, $\mathrm{pH}$ and alcohol content of maprang wine after fermentation

\begin{tabular}{|c|c|c|c|c|c|}
\hline $\begin{array}{c}\text { Controlled } \\
{ }^{\circ} \text { Brix }\end{array}$ & $\mathrm{pH}$ & $\begin{array}{l}\text { Yeast density } \\
(\text { cell } / \mathrm{mL})\end{array}$ & $\begin{array}{c}\text { TSS } \\
\text { (after fermentation) }\end{array}$ & $\begin{array}{c}\mathrm{pH} \\
\text { (after fermentation) }\end{array}$ & $\begin{array}{c}\text { Alcohol content } \\
(\% \mathrm{v} / \mathrm{v})\end{array}$ \\
\hline \multirow{9}{*}{22} & \multirow[t]{3}{*}{3.5} & $10^{3}$ & $7.0^{a b c *}$ & $3.65^{*}$ & $10^{\mathrm{de} *}$ \\
\hline & & $10^{5}$ & $7.5^{\mathrm{cd}}$ & 3.64 & $10.5^{\text {cde }}$ \\
\hline & & $10^{7}$ & $7.4^{\mathrm{bcd}}$ & 3.65 & $11^{\text {bcde }}$ \\
\hline & \multirow[t]{3}{*}{4.0} & $10^{3}$ & $6.3^{a}$ & 4.01 & $9.5^{\mathrm{e}}$ \\
\hline & & $10^{5}$ & $6.5^{\mathrm{ab}}$ & 4.02 & $10^{\text {de }}$ \\
\hline & & $10^{7}$ & $6.4^{a}$ & 3.98 & $11.5^{\text {bcd }}$ \\
\hline & \multirow[t]{3}{*}{4.5} & $10^{3}$ & $7.8^{\mathrm{cde}}$ & 4.39 & $9.5^{\mathrm{e}}$ \\
\hline & & $10^{5}$ & $8.0^{\mathrm{de}}$ & 4.55 & $9.5^{\mathrm{e}}$ \\
\hline & & $10^{7}$ & $8.0^{\mathrm{de}}$ & 4.45 & $10.5^{\text {cde }}$ \\
\hline \multirow{9}{*}{24} & \multirow[t]{3}{*}{3.5} & $10^{3}$ & $9.5^{\mathrm{h}}$ & 3.65 & $12^{\mathrm{bc}}$ \\
\hline & & $10^{5}$ & $8.5^{\text {efg }}$ & 3.64 & $12.5^{b}$ \\
\hline & & $10^{7}$ & $9.0^{\text {fgh }}$ & 3.65 & $10.5^{\text {cde }}$ \\
\hline & \multirow[t]{3}{*}{4.0} & $10^{3}$ & $8.5^{\text {efg }}$ & 4.03 & $11^{\text {bcde }}$ \\
\hline & & $10^{5}$ & $8.0^{\mathrm{de}}$ & 4.14 & $12^{\mathrm{bc}}$ \\
\hline & & $10^{7}$ & $8.1^{\text {def }}$ & 4.03 & $14.5^{a}$ \\
\hline & \multirow[t]{3}{*}{4.5} & $10^{3}$ & $9.3^{\mathrm{gh}}$ & 4.15 & $10.5^{\text {cde }}$ \\
\hline & & $10^{5}$ & $9.5^{\mathrm{h}}$ & 4.32 & $12.5^{b}$ \\
\hline & & $10^{7}$ & $9.0^{\text {fgh }}$ & 4.51 & $12.5^{b}$ \\
\hline \multirow{9}{*}{26} & \multirow[t]{3}{*}{3.5} & $10^{3}$ & $14.7^{1}$ & 3.67 & $10.5^{\mathrm{cde}}$ \\
\hline & & $10^{5}$ & $14.5^{\mathrm{kl}}$ & 3.69 & $11^{\text {bcde }}$ \\
\hline & & $10^{7}$ & $16.0^{\mathrm{m}}$ & 3.71 & $11.5^{\mathrm{bcd}}$ \\
\hline & \multirow[t]{3}{*}{4.0} & $10^{3}$ & $13.8^{\mathrm{jkl}}$ & 4.05 & $10.5^{\text {cde }}$ \\
\hline & & $10^{5}$ & $13.7^{\mathrm{jk}}$ & 4.06 & $11.5^{\mathrm{bcd}}$ \\
\hline & & $10^{7}$ & $13.5^{\mathrm{j}}$ & 4.06 & $12.5^{b}$ \\
\hline & \multirow[t]{3}{*}{4.5} & $10^{3}$ & $13.0^{\mathrm{j}}$ & 4.11 & $11^{\text {bcde }}$ \\
\hline & & $10^{5}$ & $14.5^{\mathrm{kI}}$ & 4.50 & $11.5^{\mathrm{bcd}}$ \\
\hline & & $10^{7}$ & $12.0^{i}$ & 4.48 & $12^{\mathrm{bc}}$ \\
\hline
\end{tabular}

Data are means of triplicates. Means in column with different letters are significantly different according to LSD test ( $p<0.05)$.

the growth of yeast and lactic acid bacteria is around pH 4.5 (Jacobson, 2006). At all pH, it was observed that total soluble solid (\%) decreased. This was due to sucrose utilisation by microorganism. Similar results were found by Satav and Pethe (2016) for fermentation of banana must. However, they reported low TSS content $(6 \%)$ as compared to our results $(8.1 \%)$.

Comparison of maprang wine quality producing by using isolated yeasts and commercial Saccharomyces cerevisiae

The fermentation process was done by using yeast strain $5.5 \mathrm{~A}$ ( $S$. cerevisiae, the highest fermentative activity) and commercial $S$. cerevisiae at similar fermentation conditions ( $\mathrm{pH} 4$; TSS $24 \%$ and inoculated yeast with density of $10^{5}$ cells $/ \mathrm{mL}$ ). After 12 days of fermentation, maprang wine quality produced by yeast strain $5.5 \mathrm{~A}$ was compared with maprang wine produced by commercial $S$. cerevisiae. The highest $(12.67 \% \mathrm{v} / \mathrm{v})$ and lowest $(10.33 \% \mathrm{v} / \mathrm{v})$ alcohol concentrations with corresponding residual TSS content of 5.33 and $6.87 \%$ were produced from maprang juice after fermentation with $5.5 \mathrm{~A}$ yeast strain and commercial Saccharomyces cerevisiae, respectively (Figure 2). The spidergram (Quantitative Descriptive Analysis) of sensory evaluation of maprang wine with isolated yeast strain $(5.5 \mathrm{~A})$ and commercial yeast strain (TM) is shown in Figure 3.

QDA revealed significant $(p<0.05)$ difference in sensory attributes of maprang wine produced from isolated yeast strain $5.5 \mathrm{~A}$ and commercial Saccharomyces cerevisiae. It was observed that the yeast strain 5.5A (Saccharomyces cerevisiae) was found to be the best yeast strain producing wine with the highest acceptable scores, in term of smell, taste and color. The maprang wine was fermented from isolated yeast strain showing a special taste, translucent appearance and light yellow color. 


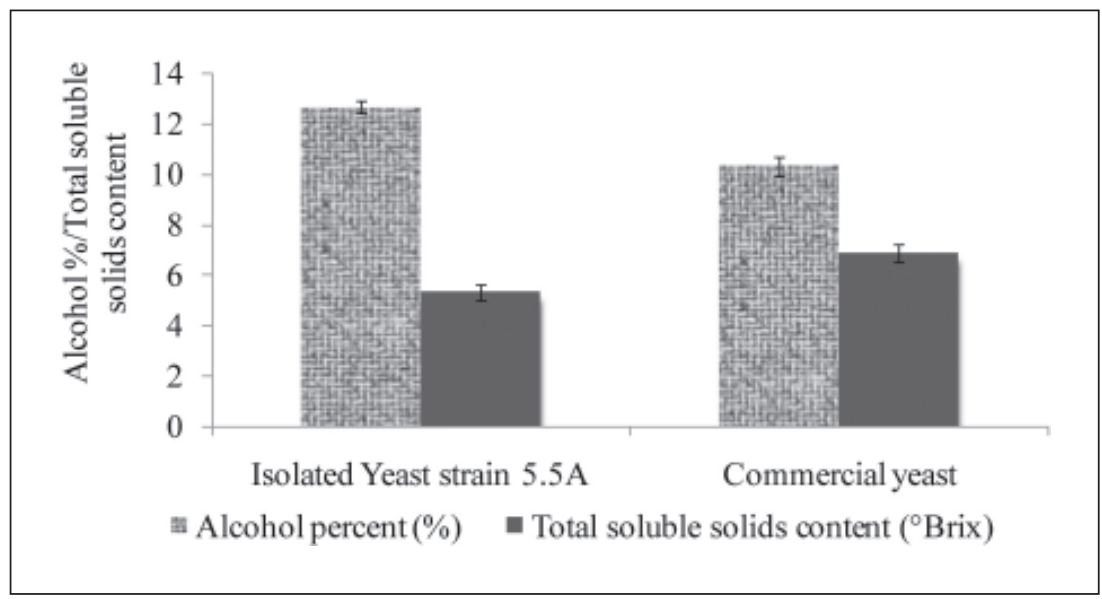

Fig. 2. Alcohol content (\%) and total soluble solid ( ${ }^{\circ}$ Brix) of maprang wine by using 5.5A and commercial Saccharomyces cerevisiae.

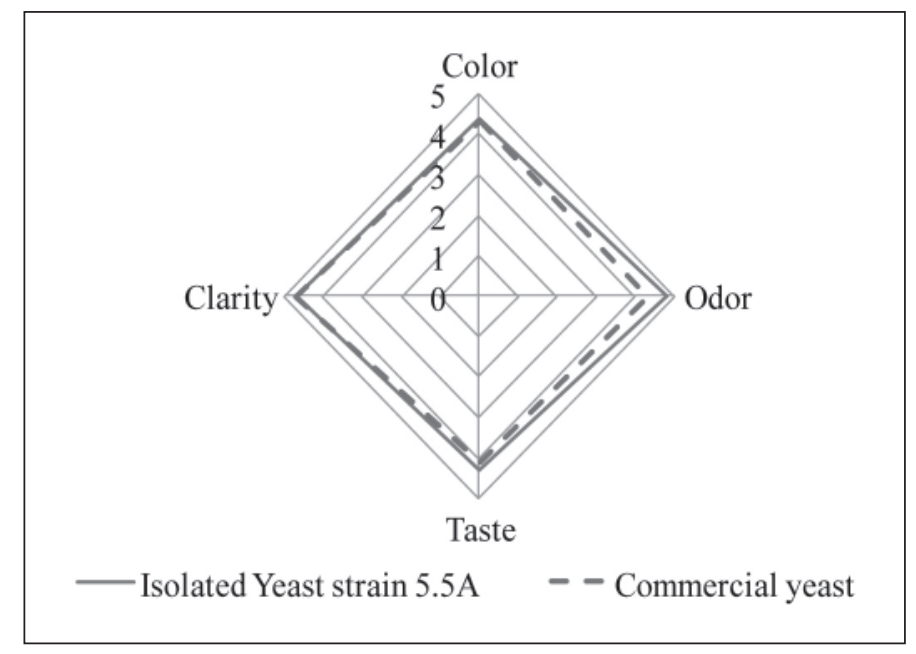

Fig. 3. Spidergram of sensory evaluation of maprang wine producing from isolated yeast strain 5.5A and commercial Saccharomyces cerevisiae.

\section{CONCLUSION}

This study has isolated and identified fifteen yeast strains from maprang belong to three genera of yeasts, such as Saccharomyces, Haseniaspora and Pichia. The isolated yeast strain $5.5 \mathrm{~A}$ was the best yeast strain for producing maprang wine with the highest ethanol $(12.57 \% \mathrm{v} / \mathrm{v})$, lowest residual sugar concentrations and highest acceptable scores. The yeast isolated from maprang showed greater ethanol yield compared to the commercial yeast. The isolated yeasts $5.5 \mathrm{~A}$ was identified as Saccharomyces cerevisiae from maprang and could be explored further for the production of maprang wine.

\section{ACKNOWLEDGEMENT}

We would like to express our gratitude to all those who gave us the possibility to complete this research. We would like to thank Department of Science and Technology of Vinh Long province for their support to our study.

\section{REFERENCES}

AOAC. 2005. Official Methods of Analysis. 15th Ed. AOAC, Washington. 
Christensen, W.B. 1946. Urea decomposition as a means of differentiating Proteus and Paracolon cultures from each other and from Salmonella and Shigella types. Journal of Bacteriology, 52: 461-66.

Clemente-Jimenez, J.M., Mingorance-Cazorla, L., Martínez-Rodríguez, S., Las Heras-Vázquez, F.J. \& Rodríguez-Vico, F. 2005. Influence of sequential yeast mixtures on wine fermentation. International Journal of Food Microbiology, 98(3): 301-8.

Dorneles, D., Machado, I.M.P., Chociai, M.B. \& Bonfim, T.M.B. 2005. Influence of the use of selected and nonselected yeasts in red wine production. Brazilian Archives of Biology and Technology, 48(5): 747-751.

Ebabhi, A.M., Adekunle, A.A., Okunowo, W.O. \& Osuntoki, A.A. 2013. Isolation and characterization of yeast strains from local food crops. Journal of Yeast and Fungal Research, 4(4): 3843.

Jacobson, J.L. 2006. Introduction to wine laboratory practices and procedures. Springer Science \& Business Media, New York. pp. 164-166, 269271.

Kurtzman, C.P. \& Fell, J.W. 1998. The yeast, A Taxonomic Study. Elsevier Science. pp. 113121.

Luong, N.D, Huyen, P.T. \& Tuyet, N.A. 2003. Practice on Bio-Technology - Vol. II. Publisher of National University of Ho Chi Minh City.

Ndip, R.N., Akoachere, J.F.K.T., Dopgima, L.L. \& Ndip, L.M. 2001. Applied Biochemistry and Biotechnology, 95: 209-20.

Satav, P.D. \& Pethe, A.S. 2016. Effect of $\mathrm{pH}$ on physicochemical parameters of wine produced from banana. International Journal of Current Microbiology and Applied Sciences, 5(2): 608613.
Thanh, N.V., Thuy, N.M., Que, T.T. \& Tuyen, N.T.M. 2013. Identification, selection and identification of yeast strains for pineapple wine fermentation. Can Tho University Journal of Science, 25: $27-$ 35.

Thuy, N.M., Nhu, N.T.H., Suong, N.T.D., Tien, N.K., Tai, N.V. \& Ly, N.T.T. 2018. Physical and chemical characteristics of maprang (Bouea macrophylla) grown in Binh Minh, Vinh Long. Journal of Agriculture and Rural Development, Specific issue: Agriculture: 18-25.

Thuy, N.M., Thanh, N.V. \& Ngan, B.T.T. 2013 b. Screening of yeast strains isolated from palm juice collected in Tinh Bien, An Giang, Viet Nam for production of palm juice wine. Mekong Food 2 Conference, Can Tho University: 386392.

Thuy, N.M., Thanh, N.V., Ngan, B.T.T. \& Cuong, N.P. 2013a. Selection of nutrient medium and identification of yeast isolates from juice collected in Tinh Bien, An Giang, Vietnam. Mekong Food 2 Conference, Can Tho University: 379-385.

Thuy, N.M., Thanh, N.V. \& Ngan, B.T.T. 2011. Selection of high activity yeast strains isolated from palm juice harvested at Tinh Bien, An Giang. Can Tho University Journal of Science, 18b: 117-123.

Vadkertiová, R., Molnárová, J., Vránová, D. \& Sláviková, E. 2012. Yeasts and yeast-like organisms associated with fruits and blossoms of different fruit trees. Canadian Journal of Microbiology, 58(12): 1344-52. 